\title{
Civil War and Child Soldiers: a Case Study of Syrian War (2013-2014)
}

\author{
Samina Noor* \\ The Islamia University of Bahawalpur \\ Pakistan
}

Received 14.05.16, received in revised form 13.06.16, accepted 22.09.16

The Syrian Crisis has eliminated all the chances of Syrian people to meet basic needs. One third of people have displaced internally and 2 million became refugees in neighbour countries. This article examines the issue of Syrian Child soldiers. They are being displaced, killed, wounded, orphaned by the ongoing civil war. Children of all genders are forced to join rebel groups. The main purpose of this study explores what kind of international legislations applied to them to protect further exploitation. In this study, discussed various world stories in contemplation to highlight the reasons why children get recruited into the rebel army.

Keywords: Syrian Crisis, Child Soldiers, Rebel Army, Civil War.

DOI: 10.17516/1997-1370-2016-9-12-2986-2994.

Research area: politology.

\section{Introduction}

"Peace is harder to win than war".

Wars always hit civilians, including children and women, badly. Although the experience of war is always severe, it creates particularly long-lasting deadly effects on children. Wars have always encroached the stages of children's development. Children get driven away from their homes, injured, killed, bullied, sexually harassed, suffer psychological and physical traumas.

Children are usually exposed to the effects of war, as they are dependent on their elders for the basic necessities of life like food, shelter, clothing, and health care. Orphaned or separated from their families, children who cannot satisfy their basic needs are likely to become child soldiers.

The Charter of the United Nations recognizes inherent dignity and equality of all people without discrimination, proclaiming it to be the very foundation of the freedom, justice, and peace in the entire world. Universal Declaration of Human Rights proclaims that all human beings are entitled to all rights and freedom regardless of their complexion, sex, race, language, religion, political and other affiliation, economic and social status, and gives children more privileges because they need more attention, care, and assistance.

According to Additional Protocols under International Humanitarian Law for the civilian and child protection, during war times ten

(C) Siberian Federal University. All rights reserved

* Corresponding author E-mail address: sameena.noor786@yahoo.com 
thousand minor children around the world are attached to different rebel groups as child soldiers.

Moreover, International Law has made multiple efforts to prevent recruiting child soldiers by rebel groups and official forces, taking care of their well-being after getting back home after the war. We can say that the international intervention has helped create considerable attention and prevent recruitment of children as soldiers at the national and local level. No doubt, after 9/11 and Arab Spring it has become a global issue which required prompt solution.

The Syrian Crisis has eliminated all the chances of Syrian people to meet their basic needs. One third of people have displaced internally and 2 million became refugees in neighbour countries. The Syrian civil war was started to overthrow President Bshar-al-Asad. In Syria, children are generally more vulnerable. They are being displaced, killed, wounded, orphaned by the ongoing civil war. Children of all genders are forced to join rebel groups.

In 1990, Syria ratified CRC (Committee on the Rights of the Children), but with the outbreak of the civil war, the government has totally failed to provide any information on the child recruitment into rebel groups. Due to lack of proper data about these child soldiers, that issue is getting more and more severe every day.

\section{Children and Wars}

The rational and peevish nature of human made him unable to live in peace. Throughout the history, the humankind has been waging conflicts and fighting for land, resources, power and prestige.

${ }^{1}$ The major part of history is written on wars, warfare, victories, defeats and humiliation of people by warriors. It has been the same from the dark ages until now. Even today the nation-states we live in are the results of wars, violent struggle and killing innocent people. Unfortunately, no rule of behaviour has been developed yet to prevent social violence during civil war.

Children are in their age of physical, mental and emotional development, and erupting wars injure them mentally, transforming their personalities.

Poor and low income states, such as African, Asian, Latin American and Middle Eastern states usually face the highest risk of armed conflicts and civil wars. In such states, various resources are less available for adults and children, but the eruption of wars makes the situation worse. In war zones, conflicts between rebels and governmental forces destroy all infrastructure including hospitals, education facilities, and accommodation, forcing children to leave.

Children taking part in armed conflicts, wars, civil wars, and revolutions have drawn international attention in the last 20 years, after boys carrying guns and girls kept as sexual slaves had widely appeared on electronic and printed media. The number of children participating in armed conflicts is growing day by day. Innocent children aged around 8-10 become brutal killers and commit the most hideous war crimes.

Children recruitment in armed rebellions is not a recent phenomenon; it has existed for ages. Looking back to the history, many young people have often been voluntarily recruited voluntarily for the sake of their nations and motherland, but rarely violently demoralized. However, the situation has become such inhumane and uncontrollable that it has attracted global attention.

War analysts have raised the point that contemporary civil wars are total societal crises, disrupting law and order all across the country. ${ }^{2}$ Such civil war societies become more dangerous for civilians, especially for women and children.

Being refugees and IDPs, children face severe challenges as they grow up. Unavailability 
of basic resources, lack of security, they are often attacked by armed groups in war zones and refugee camps.

\section{What Are Child Soldiers?}

English dictionaries define a child as "a young person of either gender" with different equivalents like "kid", "minor", "nipper", "youngster", "tyke", "nestling” etc. Generally, the word "child" refers to those young people who have not crossed the poverty line or become socially mature yet. A child passes through many stages to become a socially recognized mature.

In war zones, forced child recruitment is the main concern of rebels to enhance their powers over official forces or other enemy groups. Even after establishment of peace in war zones, child soldiers do not find their place as peaceful civilians; they may move to other destination to become soldiers again.

Thousands of children are recruited to the rebel forces around the world. Without gender discrimination, both boys and girls fight at war. We can say that it is the only one area where no gender discrimination exists. Africa, Asia, Latin America, and now the Middle East have become recruiting factories for children.

We have seen these children being recruited by force; however, most of them join the rebels voluntarily, having no opportunities of better life. Young minds are easily trapped, especially when they lose someone dear. Rebels use revenge as a tool to capture children for their purposes.

Children are fully trained as soldiers, so they are victims on one hand and are becoming killers on the other. Moreover, it is often done under great influence of drugs and alcohol. Rebels put children's life under a continuous threat and danger, training and using them as spies, messengers, suppliers, and sometimes as a shield to protect them. Girls soldiers do housekeeping for rebels and serve them sexually. These so-called "child soldiers" suffer physical and psychological consequences of living in war zones.

These child soldiers are not fully mature, so they often suffer severe injuries caused by their hard activities as soldiers. Many of them are left blind, some of them lose limbs as a result of brutal tortures by their commanders, or lose hearing due to using heavy weapons. These child soldiers are forced to perform activities for which they are not grown enough. Lack of medical assistance, lack of proper rest make their bodies more prone to trauma.

Girls are forced to live under more critical circumstances. Due to the absence of protection, many girls are infected with sexually transmitted diseases. They have poor medical assistance during pregnancy and are also forced to take care of their babies on their own.

\section{Child Soldiering and International Law}

International law has taken considerable steps to eradicate child soldiering and to build up a welfare setup for escaped child soldiers. States are adopting treaties, various measures, and other instruments foreseen by international law. International Humanitarian Law (IHL) is a part of the International Law aimed to minimize the effects of wars on people. Its main purpose is to protect innocent civilians who do not take part in the war, such as women and children.

We can say that IHL is as old as war itself, being a rudimentary form of International Law. ${ }^{3}$

An official definition of child soldier appeared after two major conferences, the first of which was held in Cape Town in 1997 and the other in Paris in 2007. The purpose of the first one was demobilization of African child soldiers; it was later held with the collaboration of UNICEF (United Nations Children's Fund) and was a global campaign. Since initial development on child soldier issues, the United Nations agencies, 
Non-Governmental Organizations (NGOs) have been playing a significant role to highlight the child soldiers' issues at high scale through conferences, workshops, electronic media, and cyberspace and have created a global opinion on that issue.

The International Committee of Red Cross (ICRC) has played a fundamental role in development and implementation of international treaties concerning military law. ${ }^{4}$ Four Geneva Conventions (1949) have formed the basic part of the IHL accepted by almost every state. These four Geneva Conventions also laid foundation for the Additional Protocols (1977) concerning protection of armed conflicts' victims.

The Four Geneva Conventions (1949) deal with the legal status of war prisoners and people injured in war zones, and seventeen provisions of these conventions address children's issues during wartime. Moreover, these protocols are less focused on children as soldiers in war zones.

However, the Geneva Conventions were completed with the Additional Protocols I, II, which address recruiting of children in rebel groups for the first time. It took fifteen more years for the enactment of the Convention on the Rights of the Child (1989) which lay down the minimum age of child recruitment during and after war times.

In 1994, the United Nations Commission on Human Rights established a working group for drafting the Optional Protocol. Many discussions were carried out by working groups, NGOs, UN Agencies, and government representatives to improve the draft text. In 2000, the Optional Protocol was formally adopted by the UN General Assembly.

The key points of the Optional Protocol are the following:

1. Direct participation of children aged under 18 in armed conflicts is forbidden (Article lof the Optional Protocol raised the age 15 to 18 years). ${ }^{5}$

2. Moreover, the Optional Protocol prohibited both voluntary and compulsory recruitment of children aged under 18 in official forces. $^{6}$

3. Article 3 of the Optional Protocol increases the minimum age of both compulsory and voluntary recruitment. ${ }^{7}$

4. Article 4 criminalizes forceful and voluntary recruitment of minors by any rebel arms groups. ${ }^{8}$

Rome Statute of the International Crime Court resolved to trial war criminals committing crimes against humanity and creating genocide on any particular racial, religious, or ethnic community. Article 8 (2)(b)(e) of the Rome Statute addresses recruiting children aged under fifteen into rebel groups and sex slavery during war times as war crimes?.

The Paris Commitments and Principles on children associated with armed forces or armed groups were endorsed by 58 countries in $2007^{10}$. The aim of this commitment is to eliminate child recruitment into armed forces and to protect children during and after armed conflicts. The UN Security Council has passed multiple resolutions on child recruitment into armed forces, killing, or exploitation as sexual slaves. ${ }^{11}$

\section{Child Protection Before Syrian Civil War}

Children recruiting in Syrian civil war is a hot debated issue nowadays. Children are recruited by both government forces and rebels not only for to enhance their force, but also to use the children as human shield. According to the estimation presented in "Save the Child", 2 million children became victims of Syrian civil war ${ }^{12}$. These children are vulnerable to malnutrition, diseases, violence, and other bitter circumstances created by government and rebel groups. These children are also bound to leave their schools and homes. 
Meanwhile, girls are put into sexual slavery and other devastating conditions.

Syrian children lost their innocence and childhood, struggling to survive. These children have been forced to live without any shelter, security, food, and medical assistance. In some parts of Syria, the entire population was forced to leave, as they could no longer survive as heavy gunship and continuous firing left no more hope.

Options of living in Syria are now closed; continuous fighting and insecurity makes it impossible for people to imagine living in a safe tomorrow. Such circumstances force them to pack in a small place for safety purposes. According to estimations, approximately 80,000 Syrian people sleep out in caves, streets, and sometime hide in ruins of demolished buildings ${ }^{13}$.

These IDPs meet their basic needs with the help of Syrian government and some international humanitarian organizations. Nevertheless, such assistance is not enough to sustain life in horrific war zones and maintain the security of people.

As we have mentioned above, the Convention on the Rights of Children is the only International treaty which ensures protection of children during war times. Syria itself ratified the CRC in 1990 and as a member to it is bound to report children's condition every year. However, since the outburst of the civil war, very little information and data actually appears. So, there is less chance to provide any assistance for the protection of children.

As a CRC signatory, the Syrian government compelled to ensure the protection of children in their jurisdiction during war time. In July 2012, the CRC called the current armed conflict that holds Syria to account before the International Law concerning children's rights.

Many domestic legislatures also dealt with child protection in Syria, such as:

1. The Syrian Commission for Family Affairs (SCFA).

\section{National Child Protection Plan.}

The first one was adopted in 2003 to monitor and coordinate the enactment of the CRC on the national level. The other task of this commission is to review the existing penal code and family law to ensure their protection of children's rights. The Syrian government announced the National Child Protection Plan in 2005 to handle sexual violence, provide protection of children and settle other family code issues. However, there was no proper mechanism to ensure the protection of children in Syria. Therefore, with the outburst of the civil war, the situation has become much worse.

\section{Child soldiers: New Blood to Civil War}

A video showing the military recruiting minor children went viral on the Internet last year ${ }^{14}$. That video showed how the militant groups transformed children into butchers. It showed children armed with rifles and other weapons, intending to kill government forces. They had been trained how to disarm and behead enemies.

Recently few more videos online showed children attending ISIL (Islamic State of Iraq and the Levant) and Jabhat-al-Nusra Jihadi training centres ${ }^{15}$. The children are taught all possible war tactics to become vicious fighters. A Jihadist website aired a video which shows a child introducing himself as a namesake of Abu Baker al Baghdadi ${ }^{16}$, wearing a black mask and being equipped with an AK-47 rifle in Syria.

These Jihadi groups attract children easily to recruit them as soldiers for many causes. They kill the elders of the families, then abduct minors and train them as soldiers. These children are easy to control, being left no other options to choose. These children have been taught the Jihadist ideology which persuades them to become suicide bombers and carry menace not only to Syria, but also to neighbouring states. 
These rebel groups create a new generation which knows nothing but how to kill, how to stab and shoot. Unfortunately, everything they learn is in the name of sharia and Jihad. The main reason for posting these videos and photographs online is to attract teenagers, showing them how powerful and strong they can be as a part of a Jihadist group. No more lies, these children have been exploited in the name of religion. Their reasons for joining these groups may vary; some of them were detained and tortured, some of them were held by government forced, which turned their minds against the government.

The Human Rights Watch (HRW) released a report on recruitment of Syrian 10-year-old children by rebel groups ${ }^{17}$. They use many tactics to trap these children, providing them with food, shelter, clothing, and, which is most important for children, promising them education, which ends up in teaching them Jihad, daydreaming of paradise, and the wonders of seventy virgin wives (Hoorain) in Jannah.

The number of the child soldiers fighting in Syria has not been estimated yet. A rough estimation was given by a local monitoring group named Violence Documenting Centre; almost 194 child soldiers have been killed since the beginning of the conflict ${ }^{18}$. This report states that recruiting minor children into fighting groups should be considered as a war crime and trialled by the International Criminal Court ${ }^{19}$. These children are vulnerable, they have no sense of what is right and what is wrong for them. They can still choose a way which would lead them to a peaceful world.

Child recruitment is also widely practiced in Kurdish controlled areas, and is aggravated when children are used as human shield or for suicide bombing. Some of them are used to carry cargo like weapons, water, food, and luggage, from one place to another. According to the Human Rights Watch, the situation in small towns is worse, as children there are trained to attack and smuggle arms and goods ${ }^{20}$.

"Allah Chose You" has become the most famous saying in Syrian civil war nowadays. The ideology behind this became the most appealing tool to make parents put send their children, along with themselves, to start a militant life. ISIS is using social media to promulgate their Jihadist ideology to attract more people, especially minor children.

"Count your children as birds in heaven" was a text message sent by a Saudi civil servant to his ex-wife, which was published by "The Pan-Arab al- Hayat" newspapers in a mother's cry $^{21}$. According to the mother, her ex-husband informed her he was going to Syria for Jihad with their two minor children aged between 10 and 11 . Recently, ISIS posted a picture of the father and his two sons on social media posing with AK-47 in one hand and a grenade in the other.

Khaled Sherrouf's story brought worldwide attention, when he posted a picture of his 7-yearold son with a detached head on Twitter. The emergence of this photo on social media revealed how militants use children as their foot soldiers ${ }^{22}$. ISIS made a documentary film, in which a foreigner comes to Syria for Jihad as a hero. Such kind of pictures, videos, and documentaries caused more Jihadists coming to Syria.

One can go far enough to say that they have converted the Hamas' use of children "as a human shield" into "turning children into killing machines", which is inhumane, brutal and unsympathetic. The other major concern is that the other side fighting the ISIS is just as evil. Last month, Kurdish armed forces demobilized 149 child soldiers, but reports still suggest that they are still recruiting and training them secretly.

The Syrian civil war affected boys and girls equally. Many tragic stories of kidnapping, detention, torture, and rape have been published. Syrian parents would lock their own daughters in 
if they failed to find grooms for them. Young girls disappear as they have never been existed before. The parents usually find unemployed grooms for their daughters, who are really unable to make a living for their folks. Such marriages usually take place without dowry, guarantee, or other legal protection for the bride. In refugee camps, life becomes even more complicated for a young girl. In such camps parents have the only option to protect their little girls from unwanted attention, which is to get them married as soon as possible. They do not even consider the age of the groom and his financial status.

"Pleasure marriages" are becoming legally justifiable to keep minor girls as sex slaves ${ }^{23}$. The atrocious massacre is the main reason behind the mass relocation of people across the borders. However, this relocation rather multiplies their problems than provide them with safety and protection. In such marriages, innocent girls are only used as sexual toys for the satisfaction of unknown men.

These pleasure marriages are legally contracted proposals which are easily accepted by parents to ensure the survival of the whole family at the cost of their daughter. These refugee camps have become the most attractive destination for sex tourists who want virgin brides to satisfy their sexual needs for an hour or a couple of days. Regrettably, girls in refugee camps have become more vulnerable to trafficking, exploitation, and sexual abuse. No place is safe for these broken angels inside Syria or beyond its borders.

\section{Conclusion}

So, we do not have any need to make extra laws for child protection; it would be more relevant to ensure implementation of the existing ones. The international standards regarding children's rights have ensured their position among its ratified members. The Optional Protocol on the children indulgence in wars has been widely welcomed all over the world. Therefore, ongoing brutality and bloodshed in many countries have drawn a question mark on the validity and concerning commitment on these legal umbrellas for children's rights. These laws need to be fully implemented on a wider scale, as now they are not enough to save the new generation.

Practical implementation is required to root down all the cases of recruiting children into the armed forces. We have a need for local and international assistance to sort out all the armed conflicts and find practical solutions to provide safe grounds for children during and after the conflicts. We need to spread knowledge and awareness of child soldiers to create a strong network and eliminate this curse. There is a need for consideration of the conflicted areas to formulate the policies that can address child soldering curse affecting the young generation.

On June 2012, the Syrian armed conflict was accepted internationally as a civil war after the humanitarian crisis. Wide-scale militarization aggravated the crisis with its horrible consequences. It is an urban armed conflict, shelling, firing, bombing of populated areas, which has affected millions of people. Moreover, millions of people had to move to the refugee camps and became dependent on humanitarian aid.

Despite limited access to Syrian conflicted areas, actual data on home loss is being collected; however, registering child casualties and assessing the scale of the problem is a difficult task. However, UN, NGOs, News Channels, and activists are releasing reports, according to which Syrian children are exposed to violence, sexual abuse, and killing. These children have now become the subject of the serious violation of the International Law and UN treaties.

It is easy to show outrage over child soldier recruitment into official and rebel groups, but 
difficult to make counteractive policies. So, health, and employment resources to the children, international actors should play their role to so that after demobilization, these child soldiers provide sustainablefinancial, technical, education, could live a better and peaceful life.

Singer, W. (2006). Children At War. California: USA. University of California Press.P.3.

Honwana, A. (2005). Child Soldiers in Africa. Pennsylvania: USA. University of Pennsylvania Press. P. 1-4.

3 Bouvier, A. (2012)..International Humanitarian Law and the Law of Armed Conflict. Retrieved 12 August, 2014 from http://cdn.peaceopstraining.org/course_promos/international_humanitarian_law/international_humanitarian_law_english.pdf

4 War and international humanitarian law.Retrieved 11Agust, 2014 from http://www.icrc.org/eng/war-and-law/index.jsp. 1) Protocol Additional to the Geneva Conventions of 12 August 1949, and relating to the Protection of Victims of International Armed Conflicts (Protocol I), 8 June 1977.

2) Convention on the Rights of the Child, 20 November 1989.

3) Optional Protocol to the Convention on the Rights of the Child on the involvement of children in armed conflict, 25 May 2000

5 ARTICLE 1

States Parties shall take all feasible measures to ensure that members of their armed forces who have not attained the age of 18 years do not take a direct part in hostilities. [Emphasis added.]

6 ARTICLE 2

States Parties shall ensure that persons who have not attained the age of 18 years are not compulsorily recruited into their armed forces.

7 ARTICLE 3

States Parties shall raise in years the minimum age for the voluntary recruitment of persons into their national armed forces from that set out in article 38, paragraph 3, of the Convention on the Rights of the Child, taking account of the principles contained in that article and recognizing that under the Convention persons under 18 are entitled to special protection.

8 ARTICLE 4

1. Armed groups that are distinct from the armed forces of a State should not, under any circumstances, recruit or use in hostilities persons under the age of 18 years.

2. States Parties shall take all feasible measures to prevent such recruitment and use, including the adoption of legal measures necessary to prohibit and criminalize such practices.

3. The application of the present article under this Protocol shall not affect the legal status of any party to an armed conflict.

The full citation of the Optional Protocol draft text can be found at http://www.icrc.org/ihl/INTRO/475?OpenDocument.

9 Article 8 (War crimes)

2.For the purpose of this Statute, «war crimes» means:

(b) Other serious violations of the laws and customs applicable in international armed conflict, within the established framework of international law, namely, any of the following acts:

(i) Intentionally directing attacks against the civilian population as such or against individual civilians not taking direct part in hostilities;

(ii) Intentionally directing attacks against civilian objects, that is, objects which are not military objectives;

(iii) Intentionally directing attacks against personnel, installations, material, units or vehicles involved in a humanitarian assistance or peacekeeping mission in accordance with the Charter of the United Nations, as long as they are entitled to the protection given to civilians or civilian objects under the international law of armed conflict;

10 Basic Principles and Paris Commitments.(2007). Retrieved 17 Agust 2014 from http://www.unicef.org/ protection/57929_58012.html.

11 These are resolutions 1261 (1999), 1314 (2000), 1379 (2001), 1460 (2003), 1539 (2004) and 1612 (2005), 1882 (2009) and 1998 (2011) on children and armed conflict. Resolutions can be found on the UN Security Council website.

12 Child soldiers on the rise in Syria, says charity. (2013). The Egypt Independent. Retrieves 13 September, 2014 from http:// www.egyptindependent.com/news/child-soldiers-rise-syria-says-charity.

13 Childhood under fire: The impact of two years of conflict in Syria. (2013). Report by Saventhe Children. Retrived 16 September, 2014 from http://protectingeducation.org/sites/default/files/documents/childhood_under_fire_embargoed_ until_13th_march.pdf.

14 Video shows militants in Syria training child soldiers. (2013). Retrieved September, 2014 from http://www.presstv.com/ detail/2013/02/09/288020/syrian-militants-train-child-soldiers/.

15 Abu Baker al Baghdadi( Leader of ISIL) - 5 July 2014, he has shown himself in a Friday sermon in Mosul, Iraq. Previously he announced himself the Caliph of Muslim Ummah, and claimed himself the decedent of Prophet Muhammad (PBUH). Go through on http:// m.bbc.com/news/world-middle-east-27801676/ for more information on this self-proclaimed Caliph.

16 Bode, D., (2014). Syrian children recruited as anti-Assad soldiers, says HRW. Retrieved 19 September, 2014 from http:// america.aljazeera.com/articles/2014/6/20/report-syrian-childsoldiersaskedtocommitsuicide.html.

17 Ibid.

18 "Majed," 16, said that Jabhat al-Nusra - a radical Islamist anti-Assad group — in Daraa promised him free schooling at a local mosque that included military training, Quran study and target practice. He said that commanders encouraged 
children to sign up for suicide attacks. "Sometimes fighters volunteered, and sometimes [commanders] said, "Allah chose you.' For further detail you will visit http://america.aljazeera.com/articles/2014/6/20/report-syrian-childsoldiersaskedtocommitsuicide.html.

19 Sherlock, Ruth. (2012). Syria using child soldiers as young as 14.Retrieved September 25, 2013 from http://www.telegraph co.uk/news/worldnews/middleeast/syria/9711971/Syria-using-child-soldiers-as-young-as-14.html.

20 Aboudi, Sami. (2014). Saudi jolts wife by taking 10 and 11-year-old boys to fight in Syria. Retrieved Saturday 27, 2014 from http://www.reuters.com/article/2014/08/12/us-syria-crisis-saudi-idUSKBN0GC0UD20140812?utm_source=twitter.

21 Khaled Sharrouf photo: Grandfather of boy holding severed head 'gutted' by photo. (Aug 12, 2014). Retrieved September, 2014 from www.cbc.ca/news/world/khaled-sharrouf-photo-grandfather-of-boy-holding-severed-head-gutted-by-photo-1 2733919 .

22 Crimi, Frank, (2013). The Selling of Syria's Refugee Child Brides. Retrieved September, 29 from http://www.frontpagemag.com/2013/frank-crimi/the-selling-of-syrias-refugee-child-brides/.

\section{Гражданская война и дети-солдаты: исследование на примере Сирийской войны (2013-2014 гг.)}

Самина Нур

Исламский университет Бахавалпура

Пакистан

$\overline{\text { Сирийский кризис лишил жителей страны любых возможностей удовлетворять свои основные }}$ потребности. Треть населения была вынуждена сменить место жительства внутри страны, а два миллиона человек стали бежениами в соседних странах. Данное исследование рассатривает проблему детей-солдат в Сирии. Продолжающаяся война вынуждает их перемещаться с места на место, их ранят, убивают, они остаются сиротами. Дети обоих полов вынуждены вступать в группы повстанцев. Основная цеель данного исследования - определить, какие виды международного законодательства можно применить для предотвращения дальнейшей эксплуатации детей. Оно рассматривает ситуации, наблюдавщиеся в различных странах мира, с целью определения причин, почему дети вступают в группы повстанцев.

Ключевые слова: Сирийский кризис, дети-солдаты, армия повстанцев, гражданская война.

Научная спеииальность: 23.00.00 - политология. 